\title{
Introduction: Historians Reflecting on History and Historical Writing, Number 1
}

\author{
Linda E. Mitchell, Senior Editor
}

T his first issue of the second decade of the twenty-first century launches a new occasional series for Historical Reflections/Réflexions Historiques: "Historians Reflecting on History and Historical Writing." The mission of the journal makes this topic particularly appropriate.

All historians, throughout their careers, confront the ways in which the history of their particular era and region is written. We all engage in an ongoing dialogue with those who precede us and with our contemporaries. Methodologies, approaches to sources, even the kinds of sources privileged have changed over time, compelling us to reassess how we think about the past, how and what we read as sources, and where we locate our scholarship in the historiographical and methodological continuum. This exercise is not solely the purview of intellectual historians; as historians of all stripes become influenced more and more by the theoretical approaches of our colleagues in the social sciences and literary criticism, we have developed new ways of seeing the past, as well as new ways of reevaluating our predecessors.

As a medieval historian, my perspective on the writing of history has inevitably been shaped by the dramatic changes medievalists have experienced in the subjects, methodologies, and theoretical approaches to their craft in the last fifty years. Whereas, in the era between the two world wars, Henri Pirenne and Marc Bloch each challenged the hegemonic notion of history as the study of the politics of the past, ${ }^{1}$ those who followed them have come now to challenge the challengers: to question their masculinist assumptions about the nature of medieval society; to develop new approaches based less upon structural-functionalist anthropological methodologies and more on those located along the postmodern continuum: feminism and post-feminism, queer theory, narratology, and postcolonialism, to suggest only a few. In this process of examination and self-reflection, medieval historians-including myself-have begun also to reflect upon the ways in which the giants upon whose shoulders we stand influenced the ways we think about the 
Middle Ages (even about the title "Middle Ages"), as we look ahead to see the possible ways in which our students and successors will challenge us.

The journal continuously receives submissions focusing on re-evaluations of notable historians and historical schools, and returning to historical questions of periodization, categorization, and specialization, from historians of all eras and genres, and from both senior and junior scholars. Reading these submissions, I have come to realize that my own ongoing internal reflection on these themes is an exercise practiced by many of my colleagues outside the medieval sandbox in which I usually play. The idea to begin an occasional series through which we could engage these questions and issues was tantalizing, and the time was opportune because of the high quality of the articles submitted for our consideration that form the core of this first issue. It is to these that I now turn.

The issue is divided into two different kinds of historiographical reflections. The first, represented by the articles by Steven Stofferahn, William Palmer, and John Herron, investigates each scholar's particular historical subfield. Steven Stofferahn engages the historical debate concerning the existence of a definable "political culture" in early medieval, especially Carolingian, Europe. William Palmer provides a re-examination of revisionist political history in the Anglo-American academy during the twentieth century, and how that re-visioning has shaped the way history is taught today. John Herron, looking both backward and forward, describes the development-and continual re-definition of-American environmental history and its position in the historical canon.

The articles by Ronald Schechter, Patrick Hutton, and John Harvey in the second half of the issue focus on the careers and legacies of specific historians or historiographical eras, and reflect on the ways in which the personal biographies of their subjects and their social and political contexts affected both their approaches to their subjects and the reception of their work. Ronald Schechter turns his eyes to the eighteenth-century European historians who defined kings and military leaders as the "terrors of their enemies," and investigates the ways in which this trope was shaped by them into a positive, rather than negative, attribution of sovereignty, one which could be successfully transplanted to the goals of the French Revolution. Patrick Hutton investigates the ways in which exile affected the career and reputation of Walter Benjamin, transforming him from a respected but little known literary critic into an "exotic intellectual celebrity," whose theory of "the role of memory in history . . intrigues scholars to this day." Finally, John Harvey illuminates the ways in which Bernard Faÿ, "the most prominent scholar of American history in the French-speaking world" in the period between the wars, shaped his view of America through the increasingly reactionary lens of his own political ideology, while paradoxically retaining the admiration and acceptance of the American historical community.

Given the circumstances by which this issue has come to fruitionthrough chance and serendipity more than through calculation and plan- 
ning-it is necessarily wide-ranging and diverse. Nevertheless, each piece can be read not just as a self-contained jewel of exemplary scholarship, but they can all be read together as representative of the perpetually questioning and self-reflexive nature of the historical profession that engages and captivates all of us. We are very proud to present these six essays as the metaphoric champagne bottle that launches our new series.

\section{Notes}

1. See, for example, Pirenne's Medieval Cities, trans. Frank D. Halsey (Princeton, 1925) and Mohammed and Charlemagne, trans. George Miall (London, 1935), and Marc Bloch, Feudal Society, trans. L. A. Manyon (Chicago, 1961). 